\title{
Predictors of Success of Mathematics Achievement of High Performing Junior High School Students
}

\author{
Maria Antonieta A. Bacabac* \\ Department of Mathematics Education, University of Science and Technology of Southern Philippines, \\ Cagayan de Oro City, Philippines \\ *Corresponding author: antonieta.bacabac@gmail.com
}

\begin{abstract}
This study was aimed at analyzing the factors affecting the mathematics achievement of the high performing Grade 10 mathematics students in selected public high schools in Cagayan de Oro City. The independent variables considered in the study were parents' occupation, parents' educational attainment, student's beliefs and attitudes towards mathematics, study habits and teacher's personal factors such as educational qualification and teaching experience. To determine if the independent variables affect the academic performance of the high performing Grade 10 students, regression analysis was used. The results revealed that the best predictors among the variables which significantly affected the achievement of the high performing Grade 10 mathematics students are father's occupation, the Grade 9 teacher's educational qualification and the Grade 9 and 10 teachers' teaching experience. The study implies that mathematics teachers have greatly influenced the mathematics achievements of the respondents. On the other hand, the father, as the head of the family, also affects the academic performance of his child. He must have an occupation or work that serves as regular source of income to support the needs of his family.
\end{abstract}

Keywords: high performing students, mathematics achievement, academic performance

Cite This Article: Maria Antonieta A. Bacabac, "Predictors of Success of Mathematics Achievement of High Performing Junior High School Students.” American Journal of Educational Research, vol. 5, no. 8 (2017): 843-847. doi: 10.12691/education-5-8-2.

\section{Introduction}

Mathematics is a language of science which is the foundation of technology. In the present cyber-space age which is technologically driven, the use of mathematics is of prime importance because of its universal and technical nature. The young generation who are expected to man the future technological world needs excellent mathematical ability to keep pace with the ever increasing demand for advancement and human needs.

Many studies have shown the importance of a scientist's contribution to economy. Findings revealed that the more scientists a country has, the better is the economy of the country. Scientists use mathematics when they analyze the data of their researches and these scientists are usually the bright students of every country. A study of why there are gifted students and how they become good in mathematics, in critical thinking necessary for creativity and innovation is of great importance especially for developing countries. In the study of Ahuja [1], he emphasized that for a country to stay competitive in the integrated global economy and to succeed in today's world crisis, the students must be good in mathematics and science. He also stressed that competency in mathematics, both in numerical manipulation and understanding its conceptual foundations, enhances a person's ability to handle the more ambitious and qualitative relationships that dominate our day-to-day decision making.

In Australia, the federal government and most states are advocating special support for the most gifted students. These students are seen as crucial contributors to a technological society in the coming generations. According to Diezmann and Watters [7], a country's prosperity is clearly dependent on a population that is scientifically literate.

Indeed, mathematically gifted students are the treasures of any nation. Gifted students are talented and are full of novel and fruitful ideas and have the ability to invent new things for the betterment of the society. These students will make positive changes in our country and the world by discovering cures for diseases, finding alternative energy resources, or inventing things that are beyond the imagination of an ordinary man.

There is a dearth of mathematically gifted students in the Philippines. This shortage is evident in the result of Trends in International Math and Science Study (TIMSS) [13] which showed that our country ranked third from the bottom among 45 participating countries all over the world. How do we go up from this level of achievement which the country has been for more than a decade? A study on the factors which might contribute to a student's mathematical excellence is necessary, hence this study is conducted. 


\section{Framework of the Study}

This study is anchored on the theory of Thorndike as cited by Bahian [2] which states that the learners are the center of the educative process and the teachers are the heart of the process. The success of students is the gauge of how effective the teaching process is done. This is done by assessing and giving worth on the performance of the students after the teaching process. Assessment is the best way to determine the performance and attainment of the students for what we assess determines what we value.

The teacher is the one who facilitates the teaching-learning process. The teacher's competence is essential in the making of a meaningful learning for behind great students are great teachers (National Council of Mathematics). The theory plays a very important role in the assessment of the mathematical skills of students. The vision which is based on the assumption that the students are capable of learning mathematics is the heart of assessment in this study.

The latest result from the Program for International Student Assessment (PISA) for student achievement in mathematics revealed that family background was related to student performance in mathematics. Students whose parents were university-educated performed about two-thirds of a proficiency level higher than those whose parents had no more than a high school education. However, there is an important nuance to add to this finding. Students whose parents worked in an occupation that required advanced mathematics skills in fact performed almost one proficiency level higher than students whose parents had similar education levels and income but whose occupation did not require advanced mathematics.

The researcher further anchors her study on the study of Batalon [3] which states that many students confirmed that their beliefs and attitudes towards mathematics, their perception of the mathematics teachers' competencies and the procedures of imparting knowledge of mathematics have greatly influenced their learning.

Teacher personal factors may also influence students' performance in mathematics. These include teachers' qualification with major fields of specialization, teachers' length of teaching experience in mathematics, and teachers' relevant in-service trainings and workshops.

Based on the study of Ruiz [11], as a teacher's academic training increases, there is a possibility that he would prefer to being left alone in his tasks, while teachers with lower educational level prefer closer supervision and explicit instruction from the supervisor to be able to perform well their tasks. She further stressed that the teacher has the basic responsibility in translating and implementing educational objectives into functional and valuable learning experiences for students. They are expected to channel to the students the skills and knowledge they have and turn these skills into productive ones. The success of a student is usually measured in terms of achievement in classroom work particularly in his academic subject. She also added that the quality of education depends largely upon the quality of teachers. To have high quality students, quality teachers are needed. The teacher should therefore maintain the highest possible standards of the profession by acquiring the prescribed qualification for the position.
Experience has been found to modify a person's behavior. Observations have shown that previous experiences cause differences in personality. Similarly, experience, may cause variations in perceptions of teachers in teaching mathematics to students. Experienced teachers are most familiar with educational content and they possess high spirits of teaching coupled with serious attitudes.

The job of a mathematics teacher requires more than a thorough knowledge of the subject matter to be taught. It demands skills in the techniques of teaching each particular topic or aspect of the subject and knowledge on how to help the students avoid or overcome difficulties.

\section{Objectives of the Study}

The researcher aimed to 1) determine whether the selected factors will influence the mathematics achievement of the high performing Grade 10 mathematics students in selected public high schools in Cagayan de Oro City; 2) determine the profile of the respondents with reference to family background in terms of parents' occupation and educational qualification, study habits, beliefs and attitudes and; 3) determine the profile of the students' mathematics teachers in terms of highest educational qualification and teaching experience.

\section{Methodology}

\subsection{Research Design}

The study used the descriptive survey research design to determine the factors affecting the performance of the high performing Grade 10 mathematics students in selected public high schools in Cagayan de Oro City. The design was specifically concerned with determining the degree of relationship among the independent variables and the dependent variables. Descriptive method of research was considered useful in establishing base line information.

\subsection{Sampling Design and Data Gathering Procedure}

The study used the purposive sampling design. The top ten high performing Grade 10 mathematics students of the randomly selected eight public high schools were purposely considered as the respondents of this study. After seeking permission and endorsement from Schools Division Superintendent, the researcher administered the questionnaires with consent from the respondents. The student-respondents answered the research questionnaires which contained the personal data sheet, the 31-item questionnaire on beliefs and attitudes towards mathematics, and the 24-item math study skills selfsurvey. The student-respondents were given 15 minutes to answer all the questions. The data for the teachers' personal factors were gathered through the teachers' survey questionnaire. The questionnaires were given to Grade 9 and Grade 10 mathematics teachers of the students who were the subjects of the study. 


\subsection{Respondents of the Study}

The top ten mathematics students of Grade 10 during the third quarter of SY 2015-2016 of the selected eight public high schools of Cagayan de Oro city were purposely considered as respondents of the study. The Grade 9 and Grade 10 mathematics teachers were also included as respondents of the study.

\subsection{Statistical Tools}

In order to determine the profile of the students with reference to their family background in terms of parents' occupation and educational qualification, beliefs and attitudes and study habits, profile of the students' mathematics teachers, mean, standard deviation, frequency and percentage were used. Multiple regression analysis was utilized to determine whether the selected factors (parents' occupation, parents' educational attainment, student's beliefs and attitudes towards mathematics, study habits and teacher's personal factors such as educational qualification and teaching experience) will influence the mathematics achievement of the high performing Grade 10 mathematics students in selected public high schools in Cagayan de Oro City.

\section{Results and Discussion}

The following tables show the data gathered and their analysis:

Table 1. Parent's Occupation

\begin{tabular}{|c|c|c|c|c|}
\hline \multirow{2}{*}{ Income Level } & \multicolumn{2}{|c|}{ Father } & \multicolumn{2}{c|}{ Mother } \\
\cline { 2 - 5 } & Frequency & Percentage & Frequency & Percentage \\
\hline 0 & 9 & 11 & 4 & 5 \\
\hline 1 & 3 & 4 & 42 & 52 \\
\hline 2 & 40 & 51 & 12 & 15 \\
\hline 3 & 20 & 25 & 12 & 15 \\
\hline 4 & 7 & 9 & 8 & 10 \\
\hline 5 & 1 & 1 & 2 & 3 \\
\hline Total & 80 & 100 & 80 & 100 \\
\hline
\end{tabular}

As shown on Table 1, majority of the fathers who are still alive are working but majority of them have below average income. Out of eighty (80) student-respondents, only one (1) student has a father who belongs to category 5 (high income). On the profile of the mothers' occupation, forty-two or $52 \%$ of the mothers out of eighty (80) belong to category 1 which means that most mothers of bright students are home makers.

Table 2. Parents' Highest Educational Attainment

\begin{tabular}{|c|c|c|c|c|}
\hline \multirow{2}{*}{$\begin{array}{c}\text { Educational } \\
\text { Attainment }\end{array}$} & \multicolumn{2}{|c|}{ Father } & \multicolumn{2}{c|}{ Mother } \\
\cline { 2 - 5 } & Frequency & Percentage & Frequency & Percentage \\
\hline Elementary & 8 & 10 & 6 & 8 \\
\hline Secondary & 33 & 41 & 30 & 38 \\
\hline Post-Secondary & 11 & 14 & 10 & 12 \\
\hline $\begin{array}{c}\text { Bachelor's } \\
\text { Degree }\end{array}$ & 19 & 24 & 21 & 26 \\
\hline Grad. Education & 9 & 11 & 13 & 16 \\
\hline Total & 80 & 100 & 80 & 100 \\
\hline
\end{tabular}

Table 2 shows that only 35\% of the fathers of the high performing Grade 10 students are professionals and $42 \%$ of the mothers of the high performing Grade 10 students are also professionals. Many of the fathers or $41 \%$ are only high school graduates while $38 \%$ of the mothers are also high school graduates.

Table 3. Beliefs and Attitudes towards Mathematics

\begin{tabular}{|c|c|c|}
\hline Description & Frequency & Percentage \\
\hline Negative Attitude & 1 & 1 \\
\hline Positive Attitude & 79 & 99 \\
\hline Total & 80 & 100 \\
\hline
\end{tabular}

A total of seventy-nine or $99 \%$ of the studentrespondents have positive beliefs and attitudes towards mathematics. This means that the high performing Grade 10 students have positive feeling towards mathematics. They like mathematics and know it is very important in life and that mathematics is relevant to their career goals. Only one or $1 \%$ of the high performing Grade 10 students has negative beliefs and attitudes towards mathematics.

Table 4. Study Habits of the High Performing Mathematics Students

\begin{tabular}{|c|c|c|}
\hline Description & Frequency & Percentage \\
\hline Bad study habit & 21 & 26 \\
\hline Good study habit & 59 & 74 \\
\hline Total & 80 & 100 \\
\hline
\end{tabular}

The data in Table 4 revealed that majority of the high performing Grade 10 mathematics students have a regular schedule of studying their lessons and assignment. This means that this group of students has cultivated good study habits.

Table 5. Educational Qualification of Grade 9 Mathematics Teachers

\begin{tabular}{|l|c|c|}
\hline Educational Qualification & Frequency & Percentage \\
\hline BSE Major in Mathematics & 5 & 63 \\
\hline With Masteral units in Mathematics & 1 & 12 \\
\hline $\begin{array}{l}\text { Completed Academic Requirements (CAR) } \\
\text { in Master's }\end{array}$ & 2 & 25 \\
\hline Graduated Masteral Degree in Mathematics & 0 & 0 \\
\hline With units in Ph. D. Mathematics & 0 & 0 \\
\hline Total & 8 & 100 \\
\hline
\end{tabular}

Table 5 shows $63 \%$ of the Grade 9 mathematics teachers did not pursue graduate school studies. Only 25\% completed the academic requirements of Master of Science in Teaching Mathematics. Nobody completed yet his /her masteral degree.

Table 6. Educational Qualification of Grade 10 Mathematics Teachers

\begin{tabular}{|l|c|c|}
\hline Educational Qualification & Frequency & Percentage \\
\hline BSE Major in Mathematics & 2 & 25 \\
\hline With masteral units in Mathematics & 2 & 25 \\
\hline $\begin{array}{l}\text { Completed Academic Requirements(CAR) } \\
\text { in Master's }\end{array}$ & 4 & 50 \\
\hline Graduated Masteral Degree in Mathematics & 0 & 0 \\
\hline With units in Ph. D. Mathematics & 0 & 0 \\
\hline Total & 8 & 100 \\
\hline
\end{tabular}


Table 6 shows that most of the Grade 10 mathematics teachers are upgrading professionally in their field of specialization to make them competent in teaching the subject. $50 \%$ already completed their academic requirements. We can notice that nobody completed yet his/her masteral degree.

Table 7. Teaching Experience of Grade 9 and 10 Mathematics Teachers

\begin{tabular}{|c|c|c|c|c|}
\hline \multirow{2}{*}{ No. of Years } & \multicolumn{2}{|c|}{ Grade 9 Teachers } & \multicolumn{2}{c|}{ Grade 10 Teachers } \\
\cline { 2 - 5 } & Frequency & Percentage & Frequency & Percentage \\
\hline 10 and below & 5 & 62 & 2 & 25 \\
\hline above 10 & 3 & 38 & 6 & 75 \\
\hline Mean & $\begin{array}{c}11.00 \text { years } \\
\text { of } \\
\text { experience }\end{array}$ & $\begin{array}{c}16.00 \text { years } \\
\text { of } \\
\text { experience }\end{array}$ \\
\hline Std Deviation & 7.00 & 7.00 \\
\hline
\end{tabular}

It can be gleaned in Table 7 that most of the Grade 9 mathematics teachers (62\%) have teaching experience of 10 years and below and 38\% also of the Grade 9 mathematics teachers have teaching experience of more than 10 years. On the other hand, $25 \%$ of the Grade 10 mathematics teachers have 10 years and below teaching experience and $75 \%$ have more than ten years of teaching experience.

Table 7 further shows the means and standard deviations of the years of teaching experience of Grade 9 and Grade 10 mathematics teachers. The Grade 10 mathematics teachers are more experienced than the Grade 9 mathematics teachers as shown by the mean of 16 years for the Grade 10 mathematics teachers as compared with the mean of 11 years for Grade 9 mathematics teachers. The years of teaching experience of Grade 9 and 10 mathematics teachers are spread farther apart resulting to a higher standard deviation of 7 .

Table 8. Mean and Standard Deviation of Students' Grades in Mathematics

\begin{tabular}{|c|c|c|c|}
\hline Mean (Grade) & Std Deviation & Highest Grade & Lowest Grade \\
\hline 92 & 3.6 & 98 & 86 \\
\hline
\end{tabular}

The students from the public high schools obtained the highest grade of 98 and the lowest grade of 86 . Their grades are quite closer which yields a standard deviation of 3.6.

Table 9. Regression Analyses of Factors Influencing Grade 10 High Performing Students' Academic Performance

\begin{tabular}{|l|c|c|}
\hline Variables & F-Value & Probability Value \\
\hline Belief and attitude towards Mathematics & 0.14 & 0.714 \\
\hline Study habits & 0.84 & 0.363 \\
\hline Father's occupation & 2.67 & $0.032^{*}$ \\
\hline Mother's occupation & 0.69 & 0.631 \\
\hline Father's educ qualification & 0.36 & 0.838 \\
\hline Mother's educ qualification & 0.79 & 0.536 \\
\hline G9 teacher educ qualification & 13.80 & $0.000 *$ \\
\hline G10 teacher educ qualification & 0.34 & 0.713 \\
\hline G9 teacher teaching experience & 15.66 & $0.000^{*}$ \\
\hline G10 teacher teaching experience & 13.88 & $0.000^{*}$ \\
\hline
\end{tabular}

$* \mathrm{p}<0.05$
Table 9 shows the result of the regression analysis of the variables assumed to influence the academic achievement of the high performing Grade 10 mathematics students. The analysis revealed that the fathers' occupation, Grade 9 mathematics teachers' educational qualification and Grade 9 and 10 mathematics teachers teaching experience came out as best predictors of students' mathematics achievement as indicated by the probability values of $0.032,0.000,0.000$ and 0.000 respectively. The result implies that the father, as the head of the family, affects the academic performance of his child. He must have an occupation or work that serves as regular source of income to support the needs of his family. Likewise, the Grade 9 teacher educational qualification affects his/her students' mathematics performance. The higher the educational qualification of the teacher, the more he/she is competent to teach the subject. Teachers' cognitive ability and content knowledge are important. Grade 10 teacher educational qualification is not a predictor of a student's mathematics performance compared to Grade 9 teacher because he was able to teach the students for three quarters only while the Grade 9 teacher taught the students for the entire school year.

The table also shows that Grade 9 and 10 mathematics teachers' teaching experience were another two factors identified to influence the mathematics performance of the students. Experienced teachers are most familiar with the educational content and they possess high spirits of teaching coupled with serious attitudes.

\section{Conclusions and Recommendations}

In light of the above results, the following conclusions were drawn: father's occupation, Grade 9 mathematics teacher educational qualification and Grade 9 and 10 teachers teaching experience are best predictors of students' mathematics performance. Beliefs and attitudes, study habits, mother's occupation, parents' educational qualification and Grade 10 mathematics teacher's educational qualification are not predictors of Grade 10 mathematics students' academic performance.

Based on the aforementioned findings and conclusions, the following recommendations are forwarded: (a) the government may consider creating more jobs especially for fathers being the head of the family; (b) universities and colleges may adopt a barangay as part of their extension programs and help develop the skills of fathers so that they can easily find a job or start a new source of income; (c) mathematics teachers were encouraged to pursue graduate studies in the field of specialization and they may avail of government scholarships; (d) school administrator may consider assigning more experienced teachers and with higher educational attainment (at least masteral graduate in mathematics education) to teach higher mathematics in high school and finally (e) the Department of Education may conduct rigid trainings for high school mathematics teachers in both content and pedagogy. 


\section{References}

[1] Ahuja, D (2003). World-class high quality mathematics education for all K-12 American students. Kent State University. Retrieved from http://www.math.umt.edu.

[2] Bahian, R. J. (2001). An evaluation of the secondary school mathematics curriculum in Cagayan de Oro City in relation to the 3rd International Mathematics and Science Study Achievement test in Mathematics. MPSC, Cagayan de Oro City.

[3] Batalon, R. E. (2005). An evaluation of the secondary senior students' performance in Mathematics in the Province of Agusan del Sur. MPSC, Cagayan de Oro City.

[4] Bussiere, Cartwright and Knighton (2004). Education Matters, December 2004, number 5, "First Results from the2003 Program for International Student Assessment (PISA)”, Catalogue number 81-004-XIE. Retrieved from. http://www.statcan.ca.

[5] Chang, F. (2006). Study on relationship among education expectations, students' self-conception, extra lessons and mathematics achievement: evidence from four dragons in TIMSS 2003. National Taipe University of Education. Retrieved from http://www.nsc.gov.tu.

[6] Chansarkar and Michaeloudis (2001). Student profiles and factors affecting performance. International Journal. Math. Educ. Sci.technol. Volume32, Number 1. Retrieved from http://www.ingentaconnect.com.
[7] Diezmann and Watters (2003). The gifted students in Science: Fulfilling potential. Queensland University of Technology. Retrieved from http://eprints.qut.edu.au/archive/00001962.

[8] Human Resources and Skills Development Canada, Council of Ministers of Education, Canada and Statistics Canada (2004). Measuring Up: Canadian Results of the OECD PISA Study: The Performance of Canada's Youth in Math, Reading, Science and Problem Solving, Vol. 2, catalogue number 81-590-XIE2004001. Retrieved from http://www.statcan.ca.

[9] Plato's view on the importance of mathematics. Retrieved from http://faculty,kfupm.edu.sa.

[10] Rice, J. (2003). Understanding the effectiveness of teacher attributes. Southwest Virginia Community College, United States of America. Retrieved from http://www.epi.org.

[11] Ruiz, A. L. (1996). Factors affecting the math performance of Grade 5 pupils in Division of Bukidnon SY 1994-1995. MPSC, Cagayan de Oro City.

[12] Thorndike, E. (1911). Connectionism. Retrieved from http://tecfa.unique.ch/themes/sa2/act-app-dos2-fic-connecti.tm.

[13] TIMSS (2003). Trends in International Math and Science Study 2003. Retrieved from http://timss.bc.edu/timss.html and http://nces.ed.gov/timss/Result03.asp.

[14] Webster, B (2001). Students' beliefs and attitudes. Curtin University of Technology, Perth, Western Australia. Retrieved from http://www.aare.edu.au. 